\title{
Investigation of Lymphocyte Subsets in Peripheral Blood of Patients with Benign Prostatic Hyperplasia
}

Ming $\mathrm{Li}^{1}, *$

Da-Ming $X \mathrm{u}^{\mathrm{l}, *}$

Shu-Bin Lin'

Zheng-Liang Yang'

Teng-Yu Xu'

Jin-Huan Yang'

Ze-Xin Lin'

Ze-Kai Huang'

Jun Yin (D) ${ }^{2,3}$

'Division of Urological Surgery, Second Affiliated Hospital of Shantou University Medical College, Shantou, Guangdong, People's Republic of China; ${ }^{2}$ Division of Hematology, Second Affiliated Hospital of Shantou University Medical College, Shantou, Guangdong, People's Republic of China; ${ }^{3}$ Department of Clinical Laboratory Medicine, Second Affiliated Hospital of Shantou University Medical College, Shantou, Guangdong, People's Republic of China

*These authors contributed equally to this work
Objective: To investigate the immune profiles in benign prostatic hyperplasia, changes in the absolute number of lymphocyte subsets and the proportion of $\mathrm{T}$ lymphocyte subsets were detected.

Methods: Absolute value of lymphocyte subsets in peripheral blood (T, B and NK cells) and the proportion of $\mathrm{T}$ lymphocyte (native $\mathrm{CD} 4^{+} \mathrm{T}$ cell, memory $\mathrm{CD} 4^{+} \mathrm{T}$ cell, $\mathrm{CD} 8^{+} \mathrm{CD} 28^{+}$ $\mathrm{T}$ cell, $\mathrm{CD} 8^{+} \mathrm{CDDR}^{+} \mathrm{T}$ cells and $\mathrm{CD} 8^{+} \mathrm{CD} 38^{+} \mathrm{T}$ cell) were measured by flow cytometry.

Results: The absolute values of $\mathrm{CD}^{+} \mathrm{T}$ cell $(972.55 \pm 330.31$ vs $1757.99 \pm 439.38), \mathrm{CD} 4^{+}$ $\mathrm{T}$ cell $(656.43 \pm 252.39$ vs $899.30 \pm 262.10)$, and $\mathrm{CD}^{+} \mathrm{T}$ cell $(301.97 \pm 147.76$ vs 728.45 \pm 230.34 ) in patients with benign prostatic hyperplasia were significantly reduced (all $P<0.05)$. There was no significant difference in NK cell $(285.58 \pm 182.84$ vs 528.92 $\pm 208.17)$ and B cell $(186.66 \pm 86.62$ vs $334.17 \pm 130.46)$. The proportion of naive CD4 ${ }^{+}$ T cell $(3.75 \pm 0.50$ vs $8.54 \pm 1.61)$ in $\mathrm{T}$ lymphocyte subsets in patients with BPH was significantly reduced $(P<0.05)$. There was no significant difference in memory $\mathrm{CD}^{+} \mathrm{T}$ cell (87.9 \pm 6.37 vs $92.63 \pm 5.94), \mathrm{CD}^{+} \mathrm{CD} 28^{+} \mathrm{T}$ cell $(60.52 \pm 13.86$ vs $64.32 \pm 12.78), \mathrm{CD}^{+} \mathrm{CDDR}^{+}$ $\mathrm{T}$ cell $(36.58 \pm 12.87$ vs $31.92 \pm 8.54)$ and $\mathrm{CD} 8^{+} \mathrm{CD} 38^{+} \mathrm{T}$ cell $(2.1 \pm 1.90$ vs $2.55 \pm 2.01)$.

Conclusion: Immune dysfunction raised the risk of viral infection, inflammatory stimulation, and tumor induction in prostate cells, leading to hyperplasia, and immune non-response was potentially a key factor in the transformation of $\mathrm{BPH}$ into prostate cancer.

Keywords: benign prostatic hyperplasia, lymphocyte subsets, pathogenesis, flow cytometry

\section{Introduction}

Benign Prostatic Hyperplasia (BPH) has become the most common cause of lower urinary tract symptoms among aging men in which prostatic epithelial hyperplasia and prostatic stromal hyperplasia lead to a range of obstructive, irritative, or mixed symptoms, such as frequent urination, urgency and dysuria. The incidence and severity of $\mathrm{BPH}$ increase with age, affecting about $70 \%$ of aging men. ${ }^{1}$ The pathophysiology of BPH has been extensively investigated, which mainly includes sex hormone theory, ${ }^{2,3}$ polypeptide growth factor theory, ${ }^{4}$ inflammatory signal transduction theory, ${ }^{5}$ cell apoptosis theory, ${ }^{6,7}$ oxidative stress theory, ${ }^{8}$ smooth muscle theory ${ }^{9}$ and other pathogenesis studies. It is generally accepted that this is a complex multifactorial disorder that accounts for the primary mechanism. Of note, patients with BPH often show an abnormal number of lymphocyte count in the blood routine in our clinical work. An abnormal number of lymphocyte counts suggest that immune dysfunction may be the pathogenesis of BPH. At present,
Department of Clinical Laboratory Medicine and Division of Hematology, The Second Affiliated Hospital of Shantou University Medical College, Dongxia Road North, Shantou, Guangdong Province, 51504I, People's Republic of China Tel +86754889I 5950

Email jyin@stu.edu.cn 
there is no research on lymphocyte subsets of $\mathrm{BPH}$ patients in domestic and foreign literature. Whether lymphocyte population can discriminate between BPH and prostate cancer or be a characteristic of this disease? Do they change in the microenvironment of the prostate tissues and induce benign hyperplasia into malignant tissue? This study is the first exploration in these fields.

Lymphocyte subsets are important indexes for evaluating immune function. They are responsible for fighting external infection and monitoring cell variation, which can be divided into $\mathrm{T}$ lymphocyte, B lymphocyte and NK cell, and $\mathrm{CD}^{+} \mathrm{T}$ cell can be divided into $\mathrm{CD}^{+}{ }^{+} \mathrm{CD} 4^{+}$cell and $\mathrm{CD}^{+}{ }^{+} \mathrm{CD} 8^{+}$cell. $\mathrm{CD}^{+}{ }^{+} \mathrm{CD} 4^{+} \mathrm{T}$ cell contains native $\mathrm{CD} 4^{+} \mathrm{T}$ cells and memory $\mathrm{CD} 4^{+} \mathrm{T}$ cell and $\mathrm{CD}^{+} \mathrm{CD}^{+} \quad \mathrm{T}$ cell contain $\mathrm{CD} 8^{+} \mathrm{CD} 28^{+} \mathrm{T}$ cell, $\mathrm{CD}^{+} \mathrm{CDDR}^{+} \mathrm{T}$ cell and $\mathrm{CD} 8^{+} \mathrm{CD} 38^{+} \mathrm{T}$ cell. In short, the aim of our research was to investigate the difference in immune profiles between BPH patients and healthy controls to reveal a new potential pathogenesis.

\section{Materials and Methods}

\section{Patient Enrollment and Blood Specimen Collection}

Thirty BPH patients (BPH group) who were hospitalized in the Division of Urological Surgery, The Second Affiliated Hospital of Shantou University Medical College from Jan 2021 to Jun 2021 were enrolled. In addition, 30 healthy men (Healthy Controls group), who presented normal blood routine and no current health problem or taking medication for three months before blood drawing, were allowed to select into our research. Patient inclusion criteria: (1) Patients underwent transurethral resection of the prostate (TURP); (2) Imaging examination suggested prostate hyperplasia. Exclusion criteria: (1) Patients with various acute infections; (2) Patients with diseases of the blood system; (3) Patients with autoimmune diseases; (4) Patients with malignant tumor; (5) Patients with coronary heart disease and hypertension; (6) Patients with endocrinerelated diseases, such as thyroid dysfunction. All the BPH patients and healthy volunteers gave their written informed consent before they enrolled into the study.

$15 \mathrm{~mL}$ whole blood sample for each patient and healthy volunteer was collected into a tube containing ethylene-diamine-tetraacetic-acid dipotassium salt (EDTA$\mathrm{K} 2$ ). The tubes were kept at room temperature and transported within 1 hour from the clinical ward to the analytical laboratory where they were immediately processed.

\section{Detection of the Absolute Value of Lymphocyte Subsets in Peripheral Blood}

According to the biologic function and the expression of surface antigen, human lymphocytes can be divided into three major subset populations: $\mathrm{T}$ lymphocytes $\left(\mathrm{CD}^{+}\right)$, B lymphocytes $\left(\mathrm{CD} 19^{+}\right)$, Natural Killer (NK) lymphocytes $\left(\mathrm{CD}^{-} \mathrm{CD}^{+} 6^{+}\right.$and/or $\left.\mathrm{CD}^{+} 6^{+}\right)$, Helper Inducer $\mathrm{T}$ lymphocytes $\left(\mathrm{CD}^{+} \mathrm{CD}^{+}\right)$and Suppressor Cytotoxic $\mathrm{T}$ lymphocytes $\left(\mathrm{CD}^{+} \mathrm{CD}^{+}\right)$. BD Multitest ${ }^{\mathrm{TM}}$ 6-color TBNK (Becton Dickinson and Company, BD Biosciences) with BD Trucount ${ }^{\mathrm{TM}}$ Absolute Count tubes (Becton Dickinson and Company, BD Biosciences) is intended for use with BD FACSCanto ${ }^{\mathrm{TM}}$ flow cytometer (Becton Dickinson and Company, BD Biosciences) to measure the absolute value of the above-mentioned lymphocyte subsets.

We confirm the BD Trucount ${ }^{\mathrm{TM}}$ bead pellets are intact and in the metal keeper at the bottom of the tube before employing the BD Trucount ${ }^{\mathrm{TM}}$ tube. For each blood sample, we mark a BD Trucount ${ }^{\mathrm{TM}}$ tube with the sample identified number. $20 \mathrm{uL}$ reagent of $\mathrm{BD}$ Multitest $^{\mathrm{TM}}$ 6-color TBNK is pipetting into the bottom of the tube without touching the bead pellet. Afterwards, $50 \mathrm{uL}$ of well-mixed, anticoagulated whole blood is pipetting into the bottom of the tube. The tube is covered and is gently vortexed to mix the sample and reagent, and then incubated at room temperature in the dark for 15 minutes. Next, we add $450 \mathrm{uL}$ of $1 \mathrm{X}$ BD FACS lysing solution into the tube. The tube ie covered and is gently vortexed to mix and incubate for another 15 minutes at the same temperature and condition mentioned above. Finally, the sample is now allowed to be analyzed by the BD FACSCanto $^{\mathrm{TM}}$ flow cytometer (Figure 1).

\section{Detection of the Proportion of T Lymphocyte Subsets in Peripheral Blood}

Twenty samples were randomly selected from BPH group and Healthy Controls group for the detection of $\mathrm{T}$ lymphocyte subsets. For each blood sample, labeling two $12 \times 75$-mm tubes with No.1 and 2. Five uL CD45RA-FITC (Becton Dickinson and Company, BD Biosciences), $4 \mathrm{uL}$ CD62L-PE (Becton Dickinson and Company, BD Biosciences), 2 uL CD4-PerCP-Cy5.5 (Becton Dickinson and Company, BD Biosciences), were added into No.1 tube. 5 uL HLA-DR-FITC (Becton Dickinson and Company, BD Biosciences), $4 \mathrm{uL}$ CD28-PE (Becton Dickinson and 

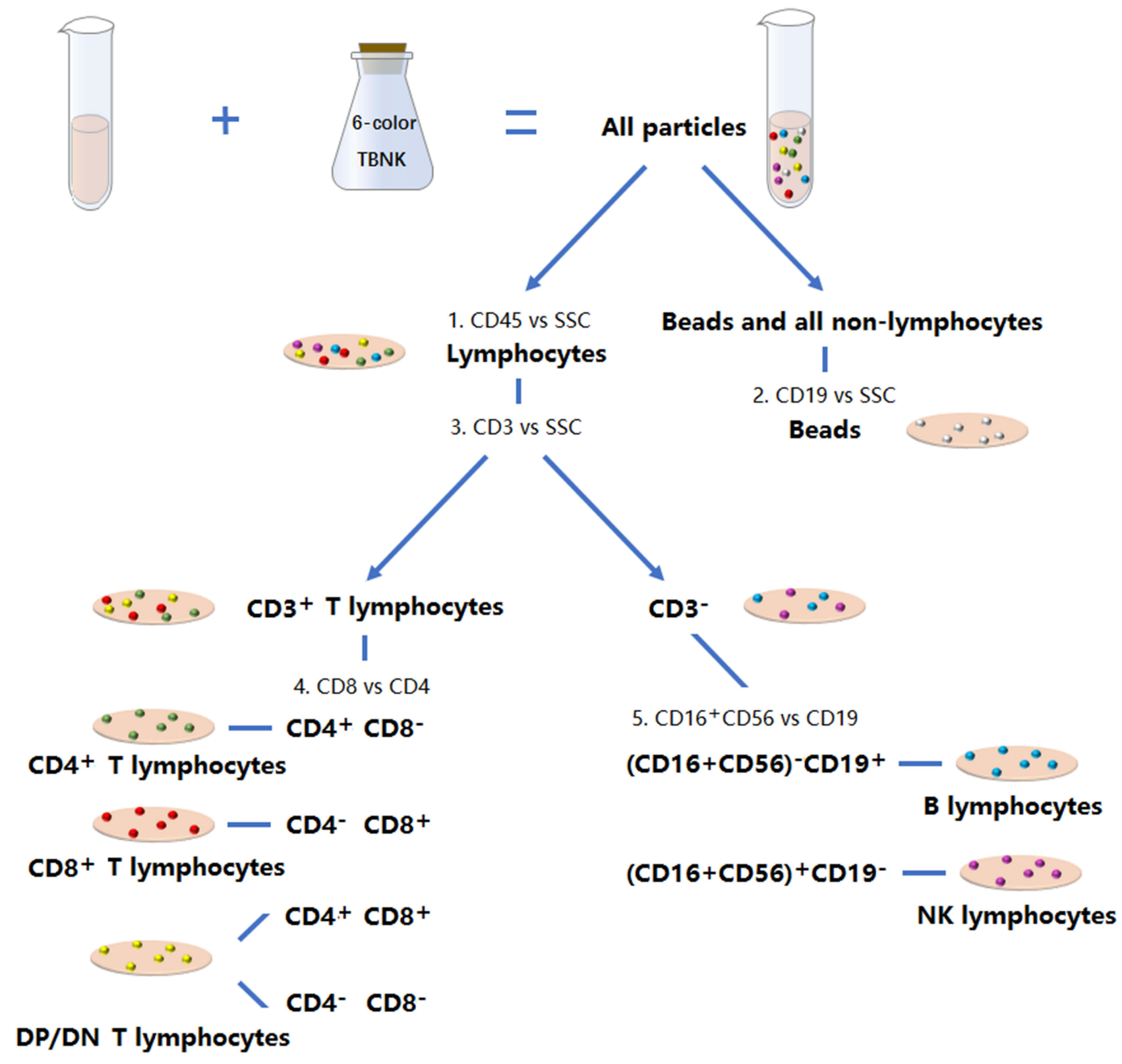

Figure I Flow diagram of BD Multitest ${ }^{\mathrm{TM}}$ 6-color TBNK reagent with BD Trucount $^{\mathrm{TM}}$ tubes.

Company, BD Biosciences), 2 uL CD4-PerCP-Cy5.5 (Becton Dickinson and Company, BD Biosciences), 2 uL CD8-PECy7 (Becton Dickinson and Company, BD Biosciences), 2 uL CD38-APC (Becton Dickinson and Company, BD Biosciences), 2 uL CD3-APC-Cy7 (Becton Dickinson and Company, BD Biosciences) were added into No. 2 tube. $50 \mathrm{uL}$ EDTA-K2 anticoagulant whole blood was, respectively, added into the No.1 and No.2 tubes, and then the tubes were mixed by eddy oscillation and incubated for 20 minutes in the dark at room temperature. $2 \mathrm{~mL}$ of hemolysin was added, and tubes were incubated for 20 minutes in the dark at room temperature, followed by centrifugation at $500 \mathrm{~g}$ for 5 minutes. After completion of centrifugation, the supernatant was poured out and the precipitation was left. $1 \mathrm{~mL}$ PBS buffer was added to resuspend the cell, and then the cell was mixed by eddy oscillation and ready to test by the $\mathrm{BD}$ FACSCanto ${ }^{\mathrm{TM}}$ flow cytometer (Figure 2).

\section{Statistical Analysis}

Data are expressed as mean \pm SD. A Student's $t$-test was allowed to apply for determining the difference between BPH group and healthy controls group. Statistical analyses were performed using the Statistical Program for Social Sciences 


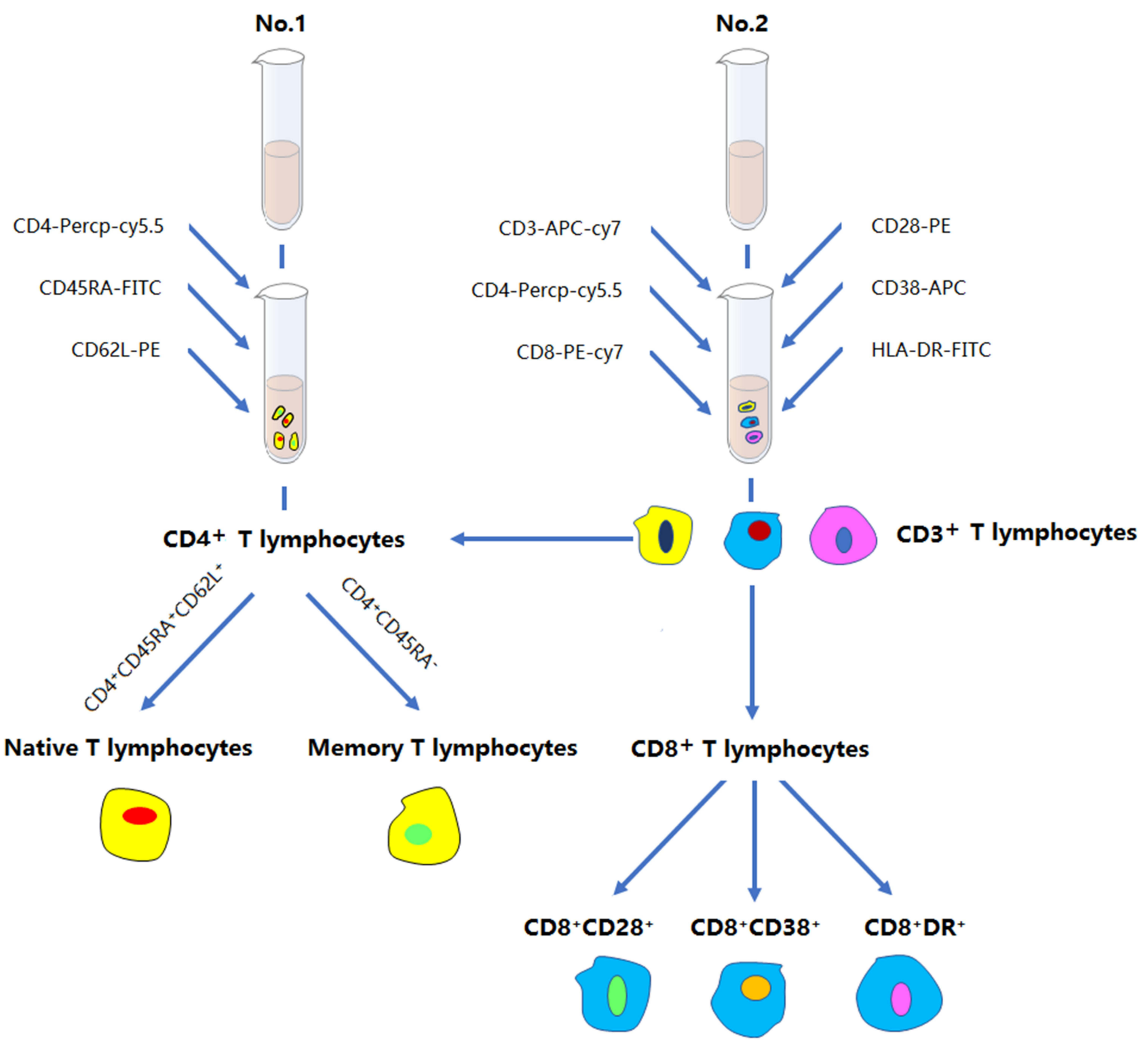

Figure 2 Flow diagram of the detection of T lymphocyte subsets by flow cytometry.

(SPSS) 25.0 software (SPSS Inc. Chicago, IL, USA). A $P$-value $<0.05$ was considered statistically significant.

\section{Results}

The Absolute Value of Lymphocyte Subsets in Peripheral Blood of Each

\section{Group}

The absolute values of $\mathrm{CD}^{+} \mathrm{T}$ cell $(972.55 \pm 330.31$ vs $1757.99 \pm 439.38), \mathrm{CD}^{+} \mathrm{T}$ cell $(656.43 \pm 252.39$ vs 899.30 $\pm 262.10)$, and $\mathrm{CD}^{+} \mathrm{T}$ cell $(301.97 \pm 147.76$ vs 728.45 $\pm 230.34)$ in patients with BPH were significantly reduced (all $P<0.05$ ). There was no significant difference in NK cell $(285.58 \pm 182.84$ vs $528.92 \pm 208.17)$ and B cell (186.66 \pm 86.62 vs $334.17 \pm 130.46)$ between $\mathrm{BPH}$ patients and healthy controls (all $P>0.05$ ) (Figure $3 \mathrm{~A}$ and $\mathrm{B}$ ).

The Proportion of T Lymphocyte Subsets in Peripheral Blood of Each Group

The proportion of naive $\mathrm{CD}^{+} \mathrm{T}$ cell $(3.75 \pm 0.50$ vs 8.54 $\pm 1.61)$ in $\mathrm{T}$ lymphocyte subsets in patients with BPH was significantly reduced $(P<0.05)$. There was no significant difference in memory $\mathrm{CD}^{+} \mathrm{T}$ cell $(87.9 \pm 6.37$ vs 92.63 $\pm 5.94), \mathrm{CD}^{+} \mathrm{CD} 28^{+} \mathrm{T}$ cell $(60.52 \pm 13.86$ vs $64.32 \pm 12.78)$, $\mathrm{CD}^{+} \mathrm{CDDR}^{+} \mathrm{T}$ cell $(36.58 \pm 12.87$ vs $31.92 \pm 8.54)$ and $\mathrm{CD}^{+} \mathrm{CD} 38^{+} \mathrm{T}$ cell $(2.1 \pm 1.90$ vs $2.55 \pm 2.01)$ between $\mathrm{BPH}$ patients and healthy controls (all $P>0.05$ ) (Figure $4 \mathrm{~A}$ and $\mathrm{B}$ ). 
A

A $\quad$ CD3/CD16+56/CD45/CD4/CD19/CD8 TruC
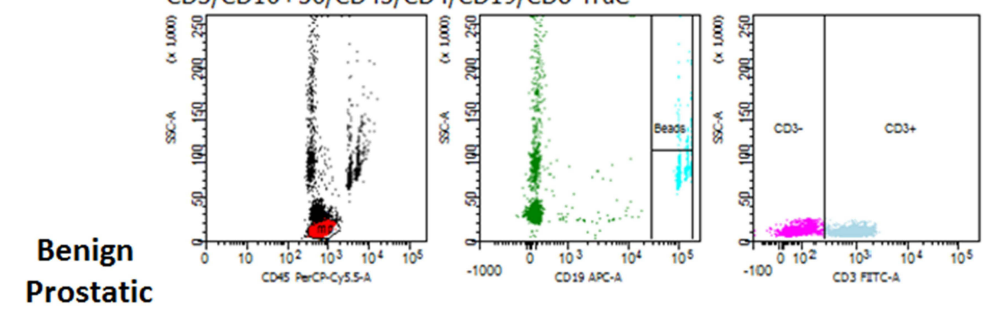

Hyperplasia
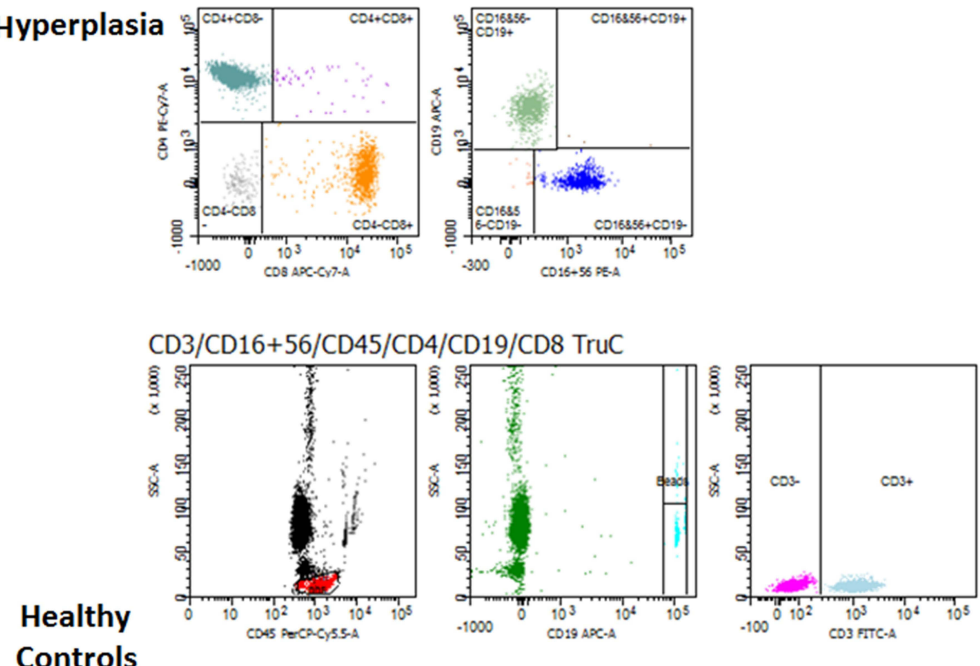

Controls
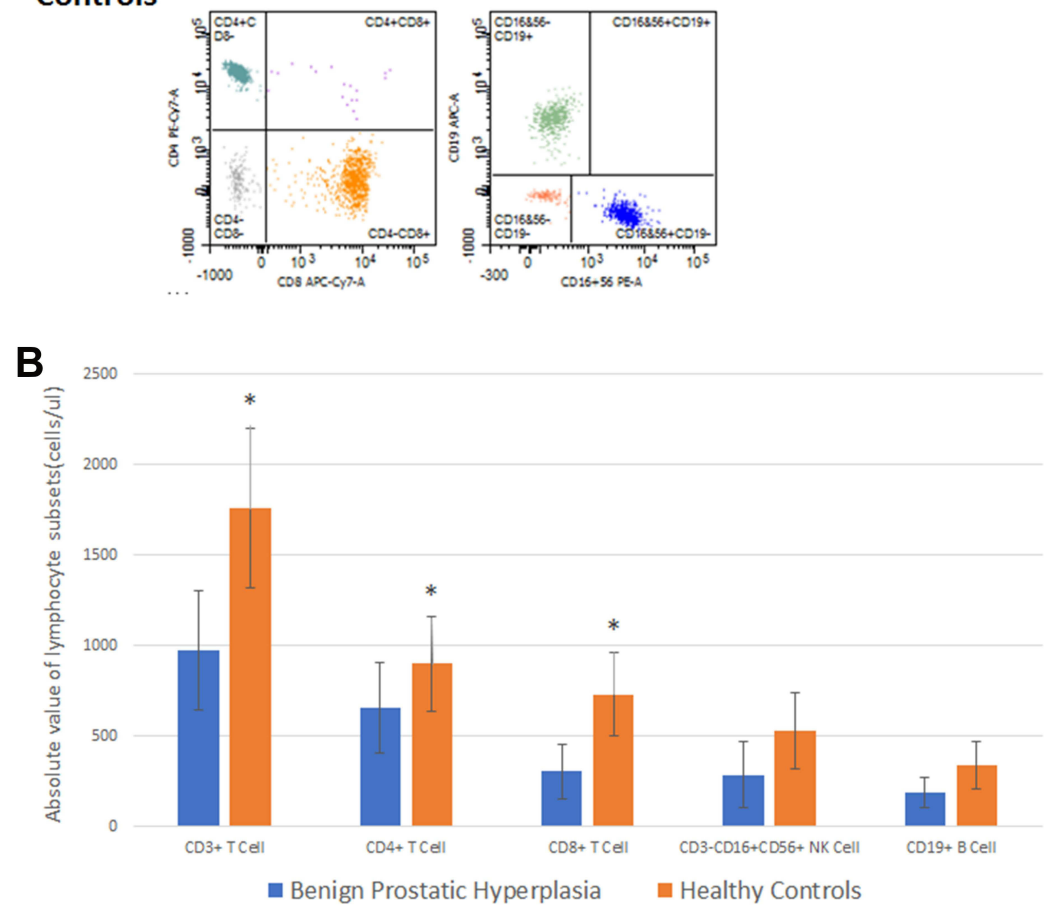

Figure 3 The absolute value of lymphocyte subsets in peripheral blood of each group. [(A) Flow cytometric results of lymphocyte subsets. (B) Histogram results of lymphoid subsets (*Comparison with the group of healthy controls $(P<0.05)]$. 


\section{Discussion}

Although the pathogenesis of $\mathrm{BPH}$ and prostate cancer remains unclear, age has been reported as the greatest risk factor. ${ }^{10} \mathrm{New}$ insights into their pathogenesis are related to prostate ageing degeneration, including the testosteron-vasculars-inflation-aging triad, as well as the cellular biological regulation of amyloidosis and autophagy. ${ }^{10}$ In addition, we note that adaptive landscapes of benign hyperplasia or malignant tissue may change when resource availability or the environment changes in favor of a subpopulation that happens to be better able to adapt to these new conditions. ${ }^{11}$ In the context of aging, the resources and environment around cells are constantly changing. Inflammation, metabolism, and mitochondrial function change significantly with age, and the accumulation of genetic mutations leads to abnormal cell renewal in tissues. $^{12}$ Henry et al found that increased inflammation associated with age reduces the fitness of B-progenitor cells and promotes the selection of progenitor cells with carcinogenic mutations, thereby restoring their fitness. ${ }^{13}$ Chronic inflammation has been demonstrated to play an important role in the pathogenesis and progression of cancer, especially in prostate cancer, by initiating epithelial-mesenchymal transformation and reshaping the extracellular matrix to modify the tumor microenvironment. ${ }^{14}$ In addition, macrophages in the prostate epithelium exhibit different subtypes consistent with changes in hormonal environment. Specific subtypes of

A
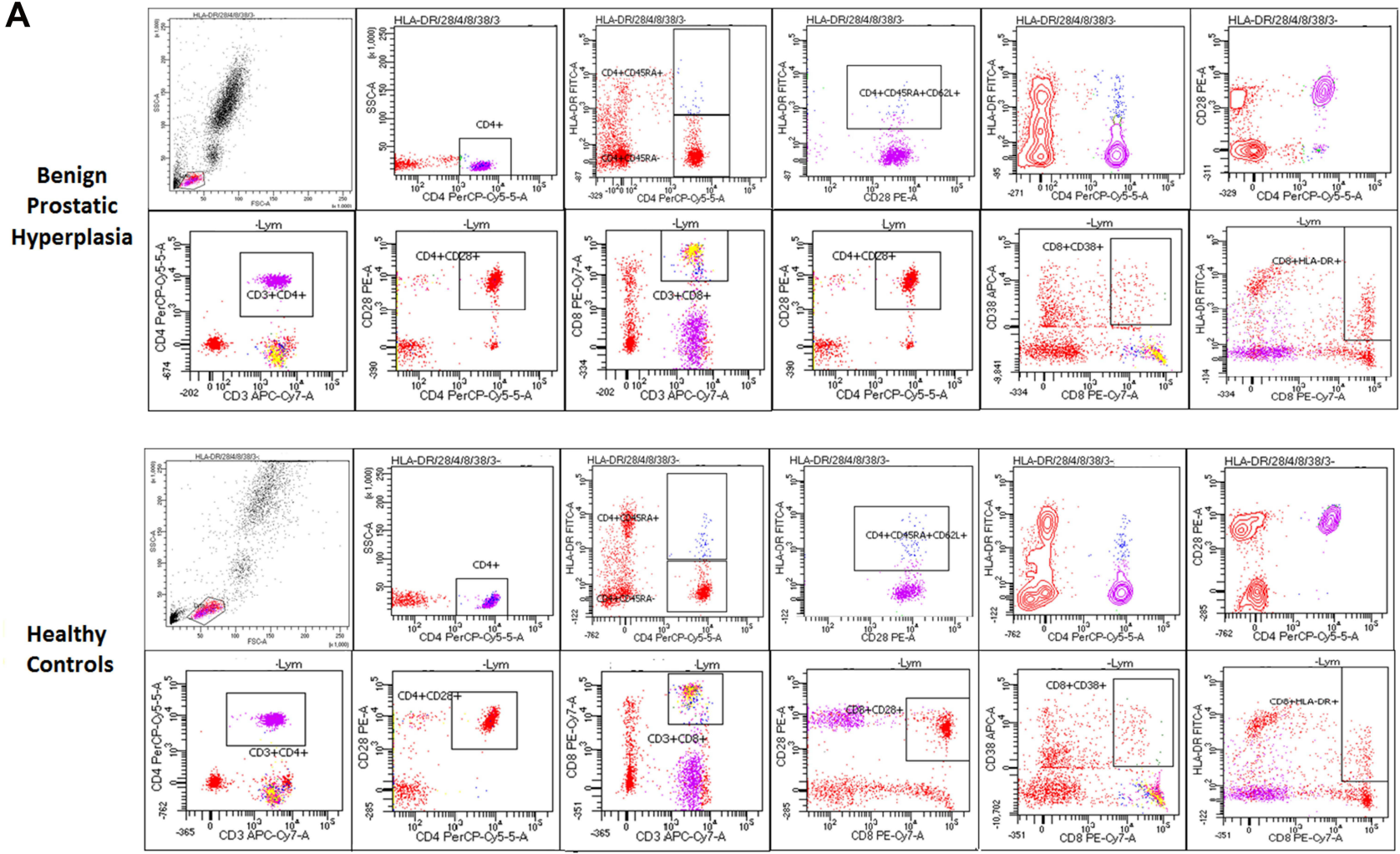

B

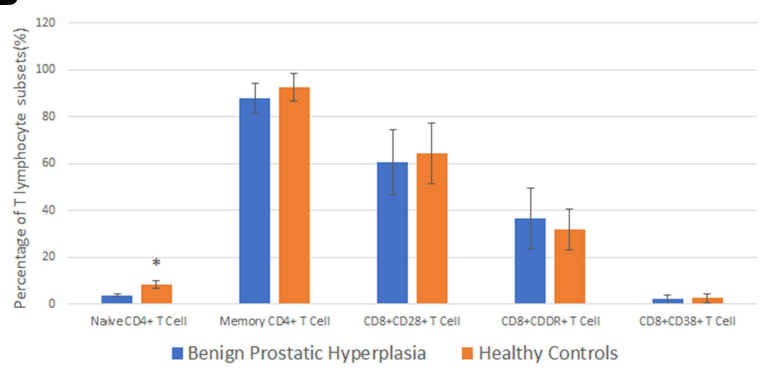

Figure 4 The proportion of T lymphocyte subsets in peripheral blood of each group. [(A) Flow cytometric results of T lymphocyte subsets. (B) Histogram results of the proportion of $\mathrm{T}$ lymphocyte subsets $(*$ Comparison with the group of healthy controls $(P<0.05)]$. 
macrophages were found to be confined to precancerous or malignant areas of the aged prostate. ${ }^{15}$

Therefore, the immune dysfunction origin of $\mathrm{BPH}$ has become an important research field in urological surgery. ${ }^{16}$ The disorder of immune microenvironment may be an important factor to stimulate prostatic hyperplasia or even induce prostatic cancer. Studies have suggested that $\mathrm{BPH}$ is an autoimmune disease in which an autoimmune response induces the proliferation of prostate epithelial and stromal cells. ${ }^{17}$ Moreover, previous experimental data indicated that acute inflammation or chronic inflammation in vivo may cause endogenous immune crossreaction, which can lead to DNA damage to cells, enhance the formation of neovascularity and increase the release of growth promoting cytokines, thus inducing hyperplasia of prostate glands. ${ }^{18}$ In our research of 30 patients diagnosed with $\mathrm{BPH}$ and healthy controls, we demonstrated that the expression of $\mathrm{CD}^{+} \mathrm{T}$ cell, $\mathrm{CD} 4^{+} \mathrm{T}$ cell and $\mathrm{CD} 8^{+} \mathrm{T}$ cell were significantly decreased in patients, whereas NK cell and $B$ cell seem to have no significant difference. In addition, our study regarding the proportion of $\mathrm{T}$ lymphocyte subsets in peripheral blood of each group demonstrated that $\mathrm{T}$ lymphocyte subsets isolated from patients with BPH had markedly decreased levels of naive $\mathrm{CD} 4^{+} \mathrm{T}$ cell and no significant difference of memory $\mathrm{CD}^{+}{ }^{+} \mathrm{T}$ cell, $\mathrm{CD} 8^{+} \mathrm{CD} 28^{+} \mathrm{T}$ cell, $\mathrm{CD} 8^{+} \mathrm{CDDR}^{+} \mathrm{T}$ cell and $\mathrm{CD} 8^{+} \mathrm{CD} 38^{+} \mathrm{T}$ cell than those in healthy controls. Of note, a prospective study of peripheral blood lymphocytes ( $\mathrm{T}$ cell, B cell and NK cell) from $31 \mathrm{BPH}$ patients undergoing prostatectomy has observed that cytotoxic $\mathrm{T}$ cell and $\mathrm{B}$ cell were in decreased expression level. ${ }^{19}$ Furthermore, another study has revealed that the autoimmune origin of BPH was the prostatic stromal cells, which can act as antigenpresenting cell to activate $\mathrm{CD} 4^{+} \mathrm{T}$ lymphocytes and induce the release of pathogenic cytokines of Th1 and Th17. ${ }^{20}$ In short, BPH patients do have immune dysfunction, especially $\mathrm{T}$ lymphocyte subsets. It is worth mentioning that our study is the first to reveal the decrease in naive $\mathrm{CD} 4^{+}$ $\mathrm{T}$ cell in the proportion of $\mathrm{T}$ lymphocyte subsets of $\mathrm{BPH}$ patients.

The mature process of $\mathrm{T}$ lymphocyte in thymus develops from the double (-) state: $\mathrm{CD} 4^{-} \mathrm{CD}^{-}$to the immature single $(+)$ state to the double $(+)$ state: $\mathrm{CD} 4^{+} \mathrm{CD} 8^{+}$and finally to single $(+)$ state: $\mathrm{CD}^{+}$or $\mathrm{CD} 8^{+}$ T lymphocyte. ${ }^{21,22}$ Under the different influences of cell microenvironment, $\mathrm{CD} 4^{+} \mathrm{T}$ cell differentiates into different subsets, naive $\mathrm{CD} 4^{+} \mathrm{T}$ cell and memory $\mathrm{CD} 4^{+} \mathrm{T}$ cell. According to different $\mathrm{T}$ lymphocyte subsets function, the subsets of naïve $\mathrm{CD} 4^{+} \mathrm{T}$ cells can be divided into $\mathrm{T}$ helper type 1 (Th1) cell, T helper type 2 (Th2) cell, T helper type 17 (Th17) cell and regulatory $\mathrm{T}$ (iTreg) cell. ${ }^{23}$ If the naive $\mathrm{T}$ cell pool is altered, adverse reactions to pathogens, tumors, and vaccines can occur, or immune deficiencies or autoimmunity can develop. ${ }^{24}$ Naive $\mathrm{CD}^{+} \mathrm{T}$ cells are usually stable in a quiescent stage, that is in the G0 phase of the cell cycle, with low activities of metabolism, transcription and translation. Metabolic changes can lead to quiescent exit of naive $\mathrm{T}$ cells, including the up-regulation of glycolysis, mitochondrial metabolism, lipid synthesis glutaminolysis and mevalonate metabolism. ${ }^{25,26}$ Study has shown that an effective adaptive immune response essentially demands a large number of naive $\mathrm{T}$ cells, which move around the body quickly recognizing almost any foreign peptide, and because the number of $\mathrm{T}$ lymphocyte decreases with age, naive $\mathrm{T}$ cells should keep in a stable long-lived stage. ${ }^{27}$ Our experimental data revealed that naive $\mathrm{CD}^{+}{ }^{+} \mathrm{T}$ cell was decreased in the proportion of $\mathrm{T}$ lymphocyte subsets in patients compared to healthy control group. However, it remains unclear as yet whether reason for the decrease in naive $\mathrm{CD}^{+} \mathrm{T}$ cell is increased destruction, decreased generation, or overexpression of quiescence exit and how microenvironment cytokines alter $\mathrm{T}$ lymphocyte at the stage of quiescence in $\mathrm{BPH}^{28}$ In recent research, Liu et al demonstrated that immune dysfunction of Th1 cell, Th2 cell, Th17 cell, iTreg cell, macrophage and their related cell factors are as common key activators in the progression of chronic prostatitis and prostate cancer. ${ }^{20}$

\section{Conclusion}

To sum up, we concluded that immune dysfunction caused by decrease of $\mathrm{T}$ lymphocyte subsets and the proportion of naive $\mathrm{CD} 4^{+} \mathrm{T}$ cell may raise the risk of viral infection, inflammatory stimulation, and tumor induction in prostate cells, leading to hyperplasia, and immune dysfunction caused by prostate ageing degeneration may have potential to be a key factor in the transformation of $\mathrm{BPH}$ into prostate cancer.

\section{Ethics Approval}

The study protocols were conducted according to the principles of the Declaration of Helsinki and were approved by the Scientific and Medical Ethical Committee of the Second Affiliated Hospital of Shantou University Medical College. 


\section{Acknowledgments}

Ming $\mathrm{Li}$ and Da-Ming $\mathrm{Xu}$ are co-first authors for this study.

\section{Author Contributions}

All authors made a significant contribution to the work reported, whether that is in the conception, study design, execution, acquisition of data, analysis and interpretation, or in all these areas; took part in drafting, revising or critically reviewing the article; gave final approval of the version to be published; have agreed on the journal to which the article has been submitted; and agree to be accountable for all aspects of the work.

\section{Funding}

There is no funding to report.

\section{Disclosure}

The authors declare that they have no competing interests.

\section{References}

1. Stoddard MD, Cho A, Te AE, Chughtai B. A systematic review on the timing of surgical intervention for benign prostatic enlargement (BPE). Curr Urol Rep. 2020;21(12):64. doi:10.1007/s11934-02001016-8

2. Asiedu B, Anang Y, Nyarko A, et al. The role of sex steroid hormones in benign prostatic hyperplasia. Aging Male. 2017;20 (1):17-22. doi:10.1080/13685538.2016.1272101

3. Chen B, Cao D, Chen Z, et al. Estrogen regulates the proliferation and inflammatory expression of primary stromal cell in benign prostatic hyperplasia. Transl Androl Urol. 2020;9(2):322-331. doi:10.21037/tau.2020.02.08

4. La Vignera S, Condorelli RA, Russo GI, Morgia G, Calogero AE. Endocrine control of benign prostatic hyperplasia. Andrology. 2016;4 (3):404-411. doi:10.1111/andr.12186

5. De Nunzio C, Presicce F, Tubaro A. Inflammatory mediators in the development and progression of benign prostatic hyperplasia. Nat Rev Urol. 2016;13(10):613-626. doi:10.1038/nrurol.2016.168

6. Singh R, Letai A, Sarosiek K. Regulation of apoptosis in health and disease: the balancing act of BCL-2 family proteins. Nat Rev Mol Cell Biol. 2019;20(3):175-193. doi:10.1038/s41580-018-0089-8

7. Wang M, Su P. The role of the Fas/FasL signaling pathway in environmental toxicant-induced testicular cell apoptosis: an update. Syst Biol Reprod Med. 2018;64(2):93-102. doi:10.1080/ 19396368.2017.1422046

8. Pace G, Di Massimo C, De Amicis D, et al. Oxidative stress in benign prostatic hyperplasia and prostate cancer. Urol Int. 2010;85 (3):328-333. doi:10.1159/000315064

9. Roehrborn CG. Pathology of benign prostatic hyperplasia. Int J Impot Res. 2008;20(Suppl 3):S11-S18. doi:10.1038/ijir.2008.55

10. Phua TJ. The etiology and pathophysiology genesis of benign prostatic hyperplasia and prostate cancer: a new perspective. Medicines. 2021;8(6):30. doi:10.3390/medicines 8060030
11. Somarelli JA, Gardner H, Cannataro VL, et al. Molecular biology and evolution of cancer: from discovery to action. Mol Biol Evol. 2020;37 (2):320-326. doi:10.1093/molbev/msz242

12. Davizon-Castillo P, McMahon B, Aguila S, et al. TNF- $\alpha$-driven inflammation and mitochondrial dysfunction define the platelet hyperreactivity of aging. Blood. 2019;134(9):727-740. doi:10.1182/ blood 2019000200

13. Henry CJ, Casás-Selves M, Kim J, et al. Aging-associated inflammation promotes selection for adaptive oncogenic events in B cell progenitors. J Clin Invest. 2015;125(12):4666-4680. doi:10.1172/ JCI83024

14. Pandareesh MD, Kameshwar VH, Byrappa K. Prostate carcinogenesis: insights in relation to epigenetics and inflammation. Endocr Metab Immune Disord Drug Targets. 2021;21(2):253-267. doi:10.2174/1871530320666200719020709

15. Werneck-Gomes H, Campolina-Silva GH, Maria BT, et al. Tumorassociated macrophages (TAM) are recruited to the aging prostate epithelial lesions and become intermingled with basal cells. Andrology. 2020;8(5):1375-1386. doi:10.1111/andr.12783

16. Tomaskovic I, Ruzic B, Trnski D, Kraus O. Chronic prostatitis/ chronic pelvic pain syndrome in males may be an autoimmune disease, potentially responsive to corticosteroid therapy. Med Hypotheses. 2009;72(3):261-262. doi:10.1016/j.mehy.2008.10.020

17. Bostanci Y, Kazzazi A, Momtahen S, Laze J, Djavan B. Correlation between benign prostatic hyperplasia and inflammation. Curr Opin Urol. 2013;23(1):5-10. doi:10.1097/MOU.0b013e32835abd4a

18. Sandhu JS. Prostate cancer and chronic prostatitis. Curr Urol Rep. 2008;9(4):328-332. doi:10.1007/s11934-008-0056-6

19. Spînu D, Mischianu D, Surcel M, et al. Immunological investigations in prostatic pathology-a prospective study. Roum Arch Microbiol Immunol. 2014;73(1-2):51-55.

20. Liu Y, Mikrani R, Xie D, et al. Chronic prostatitis/chronic pelvic pain syndrome and prostate cancer: study of immune cells and cytokines. Fundam Clin Pharmacol. 2020;34(2):160-172. doi:10.1111/ fcp. 12517

21. Chapman NM, Boothby MR, Chi H. Metabolic coordination of T cell quiescence and activation. Nat Rev Immunol. 2020;20(1):55-70. doi:10.1038/s41577-019-0203-y

22. Sprent J, Surh CD. Normal T cell homeostasis: the conversion of naive cells into memory-phenotype cells. Nat Immunol. 2011;12 (6):478-484. doi:10.1038/ni.2018

23. Zhou L, Chong MM, Littman DR. Plasticity of CD4+ T cell lineage differentiation. Immunity. 2009;30(5):646-655. doi:10.1016/j. immuni.2009.05.001

24. Smith-Garvin JE, Koretzky GA, Jordan MS. T cell activation. Annu Rev Immunol. 2009;27:591-619. doi:10.1146/annurev.immunol.021908.13 2706

25. Tarasenko TN, Pacheco SE, Koenig MK, et al. Cytochrome c oxidase activity is a metabolic checkpoint that regulates cell fate decisions during T cell activation and differentiation. Cell Metab. 2017;25 (6):1254-1268.e7. doi:10.1016/j.cmet.2017.05.007

26. Macintyre AN, Gerriets VA, Nichols AG, et al. The glucose transporter Glut1 is selectively essential for CD4 $\mathrm{T}$ cell activation and effector function. Cell Metab. 2014;20(1):61-72. doi:10.1016/j. cmet.2014.05.004

27. Mendoza A, Fang V, Chen C, et al. Lymphatic endothelial S1P promotes mitochondrial function and survival in naive $\mathrm{T}$ cells. Nature. 2017;546(7656):158-161. doi:10.1038/nature22352

28. Park Y, Jin HS, Lopez J, et al. TSC1 regulates the balance between effector and regulatory $\mathrm{T}$ cells. J Clin Invest. 2013;123 (12):5165-5178. doi:10.1172/JCI69751 


\section{Publish your work in this journal}

The International Journal of General Medicine is an international, peer-reviewed open-access journal that focuses on general and internal medicine, pathogenesis, epidemiology, diagnosis, monitoring and treatment protocols. The journal is characterized by the rapid reporting of reviews, original research and clinical studies

across all disease areas. The manuscript management system is completely online and includes a very quick and fair peer-review system, which is all easy to use. Visit http://www.dovepress.com/ testimonials.php to read real quotes from published authors. 